\title{
SISTEM PENDUKUNG KEPUTUSAN REKOMENDASI PEMBERIAN REMISI PADA NARAPIDANA MENGGUNAKAN METODE TOPSIS (STUDI KASUS PADA LEMBAGA PEMASYARAKATAN KLAS IIA PALU)
}

\author{
Decision Support System Recommendations for Remission on \\ Prisoners Using Topsis Method (A Case Study In Palu Class II-A \\ Correctional Institution)
}

\author{
A.Y. Erwin Dodu ${ }^{1}$, Yusuf Anshori ${ }^{2}$, Dennis Tandi Limbong ${ }^{3}$ \\ 1,2,3 Jurusan Teknologi Informasi, Fakultas Teknik Universitas Tadulako; \\ e-mail: ${ }^{1}$ ayerwin.dodu@gmail.com, ${ }^{2}$ iyus.jr@gmail.com
}

Received 15 / 03 / 2018, Revised 15 / 04 / 2018, Accepted 21 / 04 / 2018

\begin{abstract}
Remission is a reduction of criminal punishment given to prisoners who have been regulated in the laws of the Republic of Indonesia. The process of giving scores to inmates in Class IIA Palu Correctional Institution with certain criteria aims to facilitate the employees of Palu Class IIA to get recommendation of remission of prisoners. The decision support system in this research uses Technique for Order Preference method by Similiarity to Ideal Solution (TOPSIS) which is one of the multicriteria decision-making methods, where the basic idea of this method is that the chosen alternative has the closest distance to the ideal solution and the furthest from the ideal negative solution. In determining the inmates who receive remission recommendation in Correctional Institution Class IIA Palu there are 6 criteria which become the basis of decision making such as health condition, special skill and leadership skill, social life, never breaking order and not being a recidivist. The final result in this study is the result of calculation of proximity relative to the ideal solution that is sorted from the highest value to the lowest value so that employees of Correctional Institution Class IIA can easily take a decision on remission recommendations by looking at the results of the sorting
\end{abstract}

Keywords- Remission, Decision Support System, Technique for Order Preference by Similiarity to Ideal Solution (TOPSIS) Method;

\section{Pendahuluan}

Lembaga Pemasyarakatan sebagai ujung tombak pelaksanaan asas pengayoman merupakan tempat untuk mencapai tujuan tersebut melalui proses pendidikan, rehabilitasi dan reintegrasi dengan tujuan untuk meningkatkan kualitas warga binaan pemasyarakatan agar menyadari kesalahan dan tidak mengulangi tindak pidana kembali dilingkungan masyarakat. Hak-hak sebagai narapidana akan dibatasi ruang bergeraknya karena ditempatkan di Lembaga Pemasyarakatan. Tetapi ada hak-hak narapidana yang tetap dihormati dan dilindungi dalam Sistem Pemasyarakatan Indonesia. Salah satu hak dari narapidana yang diberikan adalah hak mendapatkan remisi. Pemberian remisi tersebut tidak hanya dilihat dari hal-hal yang menguntungkan narapidana karena akan mendapat pemotongan hukuman akibat dari pemberian remisi. Kendala yang dialami oleh petugas pemasyarakatan dalam 
sistem pemberian remisi narapidana yaitu petugas pemasyarakatan tidak dapat menentukan secara tepat narapidana yang layak dan tidak layak untuk mendapatakan remisi tambahan sehingga hal ini menyulitkan petugas pemasyarakatan untuk memberikan remisi kepada narapidana karena harus memilih satu persatu narapidana.

\subsection{Sistem Pendukung Keputusan}

Sistem Pendukung Keputusan (SPK) biasanya dibangun untuk mendukung solusi atau suatu masalah atau untuk suatu peluang. Aplikasi Sistem Pendukung Keputusan (SPK) digunakan dalam pengambilan keputusan. Aplikasi Sistem Pendukung Keputusan (SPK) menggunakan CBIS (Computer Based Information Systems) yang fleksibel, interaktif, dan dapat diadaptasi, yang dikembangakan untuk mendukung solusi atas masalah manajemen spesifik yang tidak terstruktur.

\subsection{TOPSIS (Technique for Order Preference by Similarity to Ideal Solution)}

Technique For Order Preference by Similiarity to Ideal Solution (TOPSIS)adalah salah satu metode pengambilan keputusan multikriteria yang pertama kali diperkenalkan oleh Yoon dan Hwang (1981). Ide dasarnya adalah bahwa alternatif yang dipilih memiliki jarak terdekat dengan solusi ideal dan yang terjauh dari solusi ideal negatif. Topsis memperhatikan baik jarak ke solusi ideal maupun jarak ke solusi ideal negatif dengan mengambil hubungan kedekatan menuju solusi ideal. Dengan melakukan perbandingan pada keduanya, urutan pilihan dapat ditentukan.

Langkah-langkah yang dilakukan dalam penyelesaian masalah menggunakan metode TOPSIS adalah sebagai berikut:

Langkah 1: Normalisasi matrik keputusan

Setiap elemen pada matriks $D$ di normalisasikan untuk mendapatkan matriks normalisasi $R$. setiap normalisasi dari nilai $\mathrm{r}_{\mathrm{ij}}$ dapat dilakukan dengan perhitungan

$$
r_{i j}=\frac{x_{i j}}{\sqrt{\sum_{i=1}^{m} x_{i j}^{2}}}, \begin{aligned}
\text { untuk } i & =1,2,3, \ldots, m \text { dan } ; \\
j & =1,2,3, \ldots, n
\end{aligned}
$$

Langkah 2: Pembobotan pada matrik yang telah dinormalisasi

Diberikan bobot $\mathrm{W}=\left(\mathrm{w}_{1}, \mathrm{w}_{2}, \ldots, \mathrm{w}_{\mathrm{n}}\right)$ sehingga weighted normalized matrix $V$ dapat dihasilkan sebagai berikut:

$$
\mathrm{V}_{\mathrm{ij}}=\mathrm{w}_{\mathrm{j}} \mathrm{r}_{\mathrm{ij}}
$$

dimana:

$\mathrm{i}=1,2,3, \ldots, \mathrm{m} ;$ dan $\mathrm{j}=1,2,3, \ldots, \mathrm{n}$.

$\mathrm{v}_{\mathrm{ij}}$ adalah elemen dari matriks keputusan yang ternomalisasi terbobot $\mathrm{V}$,

$\mathrm{w}_{\mathrm{j}}$ adalah bobot dari kriteria ke-j,

$\mathrm{r}_{\mathrm{ij}}$ adalah elemen dari matriks keputusan yang ternormalisasi $\mathrm{R}$. 
Langkah 3: Menentukan solusi ideal dan solusi ideal negatif

Solusi ideal dinotasikan dengan $\mathrm{A}^{+}$dan solusi ideal negatif dinotasikan dengan $\mathrm{A}^{-}$, sebagai berikut:

$$
\begin{aligned}
& \mathrm{A}^{+}=\left\{\left(\max \mathrm{v}_{\mathrm{ij}} \mid \mathrm{j} \in \mathrm{J}\right), \mathrm{i}=1,2,3, \ldots, \mathrm{m}\right\}=\left\{\mathrm{v}_{1}^{+}, \mathrm{v}_{2}{ }^{+}, \ldots, \mathrm{v}_{\mathrm{m}}{ }^{+}\right\} \\
& \mathrm{A}^{-}=\left\{\left(\min \mathrm{v}_{\mathrm{ij}} \mid \mathrm{j} \in \mathrm{J}\right), \mathrm{i}=1,2,3, \ldots, \mathrm{m}\right\}=\left\{\mathrm{v}_{1}^{-}, \mathrm{v}_{2}^{-}, \ldots, \mathrm{v}_{\mathrm{m}}\right\}
\end{aligned}
$$

Dimana:

$\mathrm{v}_{\mathrm{ij}}=$ elemen matriks $\mathrm{v}$ baris ke-I dan kolom ke-j

$\mathrm{v}_{\mathrm{j}}^{+}(\mathrm{j}=1,2,3, \ldots, \mathrm{n})$ adalah elemen matriks solusi ideal positif

$\mathrm{v}_{\mathrm{j}}^{-}(\mathrm{j}=1,2,3, \ldots, \mathrm{n})$ adalah elemen matriks solusi ideal negatif

\section{Langkah 4: Menghitung separation measure}

Separation measure ini merupakan pengukuran jarak dari suatu alternatif ke solusi ideal dan solusi ideal negatif. Perhitungan matematisnya adalah sebagai berikut:

a. Solusi ideal

$$
\mathrm{S}_{\mathrm{i}}^{+}=\sqrt{\sum_{i=1}^{n}\left(v_{i j}-v_{j}^{+}\right)^{2}}
$$

untuk $\mathrm{i}=1,2,3, \ldots, \mathrm{m}$

Dimana:

$\mathrm{S}_{\mathrm{i}}^{+}$adalah jarak alternatif ke-i dari solusi ideal positif,

$\mathrm{v}_{\mathrm{ij}}$ adalah elemen dari matriks keputusan yang ternomalisasi terbobot $\mathrm{V}$,

$\mathrm{v}_{\mathrm{j}}^{+}$adalah element matriks solusi ideal positif

b. Solusi ideal negative

$$
\mathrm{S}_{\mathrm{i}}^{-}=\sqrt{\sum_{i=1}^{n}\left(v_{i j}-v_{j}^{-}\right)^{2}}
$$

untuk $\mathrm{i}=1,2,3, \ldots, \mathrm{m}$

Dimana:

$\mathrm{S}_{\mathrm{i}}^{-}$adalah jarak alternatif ke-i dari solusi ideal negatif,

$\mathrm{v}_{\mathrm{ij}}$ adalah elemen dari matriks keputusan yang ternomalisasi terbobot $\mathrm{V}$, $\mathrm{v}_{\mathrm{j}}$ adalah element matriks solusi ideal negatif.

Langkah 5: Menghitung kedekatan realatif dengan solusi ideal

Kedekatan relatif dari alternatif $\mathrm{A}_{\mathrm{i}}$ dengan solusi ideal $\mathrm{A}^{+}$dipresentasikan dengan:

$$
\mathrm{C}_{\mathrm{i}}^{+}=\frac{S_{i}^{-}}{\left(S_{i}^{-}+S_{i}^{+}\right)}
$$

Dimana:

$\mathrm{i}=1,2,3, \ldots \mathrm{m}$

$\mathrm{C}_{\mathrm{i}}^{+}$adalah kedekatan relatif dari alternatif ke-i terhadap solusi ideal

$\mathrm{S}_{\mathrm{i}}^{+}$adalah jarak alternatif ke-i dari solusi ideal positif 
$\mathrm{S}_{\mathrm{i}}^{-}$adalah jarak alternatif ke-i dari solusi ideal negatif.

Langkah 6: Mengurutkan Pilihan

Pilihan akan diurutkan berdasarkan pada nilai $\mathrm{C}_{\mathrm{i}}^{+}$, sehingga alternatif dengan jarak terpendek dengan solusi ideal adalah alternatif yang terbaik.

\subsection{Penyelesaian Masalah Menggunakan Metode TOPSIS}

Kriteria yang digunakan dalam penyelesaian masalah pemberian rekomendasi remisi pada narapadina yaitu:

$\mathrm{K} 1=$ Kondisi Kesehatan

K2= Kecakapan dan Ketrampilan Khusus

K3= Mempunyai Bakat Pemimpin

K4= Mempunyai Jiwa Sosial

K5 $=$ Tidak Pernah Melanggar Tata Tertib

K6= Bukan Merupakan Residivis

Dengan bobot setiap kriteria sebagai berikut:

$\begin{array}{ll}\mathrm{K} 1=3 & \mathrm{~K} 4=4 \\ \mathrm{~K} 2=3 & \mathrm{~K} 5=4 \\ \mathrm{~K} 3=4 & \mathrm{~K} 6=4\end{array}$

\begin{tabular}{|c|c|c|c|c|c|c|c|}
\hline No & No Register & K1 & K2 & K3 & K4 & K5 & K6 \\
\hline 1. & BI/001/2015 & 4 & 2 & 2 & 3 & 3 & 3 \\
\hline 2. & BI/002/2015 & 4 & 3 & 1 & 2 & 2 & 4 \\
\hline 3. & BI/031/2015 & 3 & 4 & 1 & 2 & 3 & 4 \\
\hline 4. & $\mathrm{BI} / 048 / 2015$ & 3 & 2 & 1 & 3 & 3 & 3 \\
\hline 5. & $\mathrm{BI} / 050 / 2015$ & 4 & 3 & 2 & 2 & 4 & 4 \\
\hline 6. & $\mathrm{BI} / 098 / 2014$ & 4 & 3 & 2 & 4 & 3 & 4 \\
\hline 7. & $\mathrm{BI} / 102 / 2014$ & 4 & 2 & 1 & 2 & 2 & 3 \\
\hline 8. & $\mathrm{BI} / 154 / 2014$ & 4 & 3 & 1 & 2 & 2 & 4 \\
\hline 9. & $\mathrm{BI} / 197 / 2013$ & 4 & 3 & 2 & 3 & 2 & 3 \\
\hline
\end{tabular}

Gambar 1. Inputan nilai setiap kriteria pada narapidana

1. Menentukan normalisasi matriks keputusan.

$$
\begin{aligned}
& \mathrm{X} 1=\sqrt{4^{2}+4^{2}+3^{2}+3^{2}+4^{2}+4^{2}+4^{2}+4^{2}+4^{2}}=11.402 \\
& \mathrm{R}_{11}=\frac{X 11}{[X 1]}=\frac{4}{11.402}=0.3508 \\
& \mathrm{R}_{21}=\frac{X 21}{[X 1]}=\frac{4}{11.402}=0.3508 \\
& \mathrm{R}_{31}=\frac{X 31}{[X 1]}=\frac{3}{11.402}=0.2631
\end{aligned}
$$




$$
\begin{aligned}
& \mathrm{R}_{41}=\frac{X 41}{[X 1]}=\frac{3}{11.402}=0.2631 \\
& \mathrm{R}_{51}=\frac{X 51}{[X 1]}=\frac{4}{11.402}=0.3508 \\
& \mathrm{R}_{61}=\frac{X 61}{[X 1]}=\frac{4}{11.402}=0.3508 \\
& \mathrm{R}_{71}=\frac{X 71}{[X 1]}=\frac{4}{11.402}=0.3508 \\
& \mathrm{R}_{81}=\frac{X 81}{[X 1]}=\frac{4}{11.402}=0.3508 \\
& \mathrm{R}_{91}=\frac{X 91}{[X 1]}=\frac{4}{11.402}=0.3508 \\
& \mathrm{R}_{36}=\frac{X 36}{[X 6]}=\frac{4}{10.770}=0.3714 \\
& \mathrm{R}_{26}=\frac{X 26}{[X 6]}=\frac{4}{10.770}=0.3714 \\
& \mathrm{R}_{12}=\frac{X 12}{[X 2]}=\frac{2}{8.544}=0.2341 \\
& \mathrm{R}_{92}=\frac{X 92}{[X 2]}=\frac{3}{8.544}=0.3511 \\
& \mathrm{R}_{22}=\frac{X 22}{[X 2]}=\frac{3}{8.544}=0.3511 \\
& \mathrm{R}_{72}=\frac{X 72}{[X 2]}=\frac{2}{8.544}=0.2341 \\
& \mathrm{R}_{32}=\frac{X 32}{[X 2]}=\frac{4}{8.544}=0.4682 \\
& \mathrm{R}_{42}=\frac{X 42}{[X 2]}=\frac{X}{8.544}=0.2341 \\
& {[X 2]}
\end{aligned}
$$




$$
\begin{aligned}
& \mathrm{R}_{46}=\frac{X 46}{[X 6]}=\frac{3}{10.770}=0.2785 \\
& \mathrm{R}_{56}=\frac{X 56}{[X 6]}=\frac{4}{10.770}=0.3714 \\
& \mathrm{R}_{66}=\frac{X 66}{[X 6]}=\frac{4}{10.770}=0.3714 \\
& \mathrm{R}_{76}=\frac{X 76}{[X 6]}=\frac{3}{10.770}=0.2785 \\
& \mathrm{R}_{86}=\frac{X 86}{[X 6]}=\frac{4}{10.770}=0.3714 \\
& \mathrm{R}_{96}=\frac{X 96}{[X 6]}=\frac{3}{10.770}=0.2785
\end{aligned}
$$

\begin{tabular}{|c|c|c|c|c|c|c|}
\hline $\mathrm{V}_{1}=$ & $0.3508 * 3$ & $0.2341^{*} 3$ & $0.4364 * 4$ & $0.3780^{*} 4$ & $0.3638 * 4$ & - \\
\hline$V_{2}=$ & 0.35 & 0.3 & $* 4$ & $* 4$ & $* 4$ & \\
\hline $\mathrm{V}_{3}=$ & 0.26 & 3 & 4 & 4 & 4 & \\
\hline$V_{4}=$ & & & & & & \\
\hline $\mathrm{V}_{5}=$ & 0 & 0.3 & 4 & $* 4$ & $* 4$ & \\
\hline $\mathrm{V}_{6}=$ & 0.3 & 0.3 & 0.4 & 0.5 & & \\
\hline $\mathrm{V}_{7}=$ & $0.3508 * 3$ & $0.2341 * 3$ & $2182 * 4$ & $0 * 4$ & 0.2 & $0.2785^{*} 4$ \\
\hline $\mathrm{V}_{8}=$ & & 0.3 & & & & \\
\hline $\mathrm{V}_{9}=$ & 0.3. & & $0.4504+4$ & $0.3780^{*} 4$ & $0.2425^{*} 4$ & 0.2785 \\
\hline
\end{tabular}

Diperoleh matriks R seperti dibawah ini:

\begin{tabular}{|c|c|c|c|c|c|c|}
\hline & 0.3508 & 0.2341 & 0.4364 & 0.3780 & 0.3638 & 0.2785 \\
\hline 0.3508 & 0.3511 & 0.2182 & 0.2520 & 0.2425 & 0.3714 \\
\hline 0.2631 & 0.4682 & 0.2182 & 0.2520 & 0.3638 & 0.3714 \\
\hline 0.2631 & 0.2341 & 0.2182 & 0.3780 & 0.3638 & 0.2785 \\
\hline 0.3508 & 0.3511 & 0.4364 & 0.2520 & 0.4851 & 0.3714 \\
\hline 0.3508 & 0.3511 & 0.4364 & 0.5040 & 0.3638 & 0.3714 \\
\hline 0.3508 & 0.2341 & 0.2182 & 0.2520 & 0.2425 & 0.2785 \\
\hline 0.3508 & 0.3511 & 0.2182 & 0.2520 & 0.2425 & 0.3714 \\
\hline 0.3508 & 0.3511 & 0.4364 & 0.3780 & 0.2425 & 0.2785 \\
\hline
\end{tabular}

Gambar 2. Matriks R

2. Menentukan matriks keputusan yang ternomalisasi terbobot.

Gambar 3. Matriks keputusan yang ternomalisasi terbobot

Maka didapatkan matriks dibawah ini

\begin{tabular}{|l|l|l|l|l|l|l|}
\hline & 1.0525 & 0.7022 & 1.7457 & 1.5119 & 1.4552 & 1.1142 \\
\hline 1.0525 & 1.0534 & 0.8729 & 1.0079 & 0.9701 & 1.4856 \\
\hline 0.7894 & 1.4045 & 0.8729 & 1.0079 & 1.4552 & 1.4856 \\
\hline 0.7894 & 0.7022 & 0.8729 & 1.5119 & 1.4552 & 1.1142 \\
\hline $\mathrm{V}=$ & 1.0525 & 1.0534 & 1.7457 & 1.0079 & 1.9403 & 1.4856 \\
\hline 1.0525 & 1.0534 & 1.7457 & 2.0158 & 1.4552 & 1.4856 \\
\hline 1.0525 & 0.7022 & 0.8729 & 1.0079 & 0.9701 & 1.1142 \\
\hline 1.0525 & 1.0534 & 0.8729 & 1.0079 & 0.9701 & 1.4856 \\
\hline 1.0525 & 1.0534 & 1.7457 & 1.5119 & 0.9701 & 1.1142 \\
\hline
\end{tabular}

Gambar 4. Hasil Matriks Keputusan 
3. Menentukan matriks solusi ideal positif dan ideal negatif.

$\begin{array}{ll}\text { Ideal Positif } & \text { Ideal Negatif } \\ 1.0525 & 0.7894 \\ 1.4045 & 0.7022 \\ 1.7457 & 0.8729 \\ 2.0158 & 1.0079 \\ 1.9403 & 0.9701 \\ 1.4856 & 1.1142\end{array}$

4. Menghitung Separation Measure

a. ideal positif

$$
\begin{aligned}
S_{i}^{+} & =\sqrt{\sum_{i=1}^{n}\left(V_{i}^{+}-V_{i j}\right)^{2}} \\
\mathrm{~S}_{1}+ & =\sqrt{\begin{array}{l}
(1.0525-1.0525)^{2}+(0.7022-1.4045)^{2}+ \\
(1.7457-1.7457)^{2}+(1.5119-2.0158)^{2}+ \\
(1.4552-1.9403)^{2}+(1.1142-1.4856)^{2}
\end{array}} \\
& =1.0585 \\
\mathrm{~S}_{2}{ }^{+} & =\sqrt{\begin{array}{l}
(1.0525-1.0525)^{2}+(1.0534-1.4045)^{2}+ \\
(0.8729-1.7457)^{2}+(1.0079-2.0158)^{2}+ \\
(0.9701-1.9403)^{2}+(1.4856-1.4856)^{2}
\end{array}} \\
& =1.6859 \\
\mathrm{~S}_{3}{ }^{+} & =\sqrt{\begin{array}{l}
(0.7894-1.0525)^{2}+(1.4045-1.4045)^{2}+ \\
(1.4552-1.9403)^{2}+(1.4856-1.4856)^{2}
\end{array}} \\
& =1.4430 \\
\mathrm{~S}_{9}{ }^{+} & =\sqrt{\begin{array}{l}
(1.0525-1.0525)^{2}+(1.0534-1.4045)^{2}+ \\
\left.(0.9701-1.945)^{2}+1.9403\right)^{2}+(1.1142-1.4856)^{2}
\end{array}} \\
& =1.2068
\end{aligned}
$$

b. ideal negatif

$$
\begin{aligned}
S_{i}^{-} & =\sqrt{\sum_{i=1}^{n}\left(V_{i j}-V_{i}^{-}\right)^{2}} \\
\mathrm{~S}_{1}{ }^{-} & =\sqrt{\begin{array}{l}
(1.0525-0.7894)^{2}+(0.7022-0.7022)^{2}+ \\
(1.7457-0.8729)^{2}+(1.5119-1.0079)^{2}+
\end{array}} \\
& =1.1491
\end{aligned}
$$




$$
\begin{aligned}
\mathrm{S}_{2}{ }^{-} & =\sqrt{\begin{array}{l}
(1.0525-0.7894)^{2}+(1.0534-0.7022)^{2}+ \\
(0.8729-0.8729)^{2}+(1.0079-1.0079)^{2}+ \\
(0.9701-0.9701)^{2}+(1.4856-1.1142)^{2}
\end{array}} \\
& =0.5748 \\
\mathrm{~S}_{3}{ }^{-} & =\sqrt{\begin{array}{l}
(0.7894-0.7894)^{2}+(1.4045-0.7022)^{2}+ \\
(0.8729-0.8729)^{2}+(1.5119-1.0079)^{2}+ \\
(1.4552-0.9701)^{2}+(1.4856-1.1142)^{2}
\end{array}} \\
& =0.9308 \\
\mathrm{~S}_{9}{ }^{-} & =\sqrt{\begin{array}{l}
(1.0525-0.7894)^{2}+(1.0534-0.7022)^{2}+ \\
(1.7457-0.8729)^{2}+(1.5119-1.0079)^{2}+ \\
(0.9701-0.9701)^{2}+(1.1142-1.1142)^{2}
\end{array}} \\
& =1.0993
\end{aligned}
$$

5. Menghitung kedekatan realatif dengan solusi ideal

$$
\begin{aligned}
& \mathrm{C}_{\mathrm{i}}=\frac{S_{i}^{-}}{S_{i}^{-}+S_{i}^{+}} \\
& \mathrm{C}_{1}=\frac{1.1491}{1.1491+1.0585}=0.5205 \\
& \mathrm{C}_{2}=\frac{0.5748}{0.5748+1.6859}=0.2543 \\
& \mathrm{C}_{3}=\frac{0.9308}{0.9308+1.4430}=0.3921 \\
& \mathrm{C}_{4}=\frac{0.6995}{0.6995+1.3970}=0.3337 \\
& \mathrm{C}_{5}=\frac{1.4260}{1.4260+1.0673}=0.5719 \\
& \mathrm{C}_{6}=\frac{1.5309}{1.5309+0.5988}=0.7188 \\
& \mathrm{C}_{7}=\frac{0.2631}{0.2631+1.8303}=0.1257 \\
& \mathrm{C}_{8}=\frac{0.5748}{0.5748+1.6859}=0.2543 \\
& \mathrm{C}_{9}=\frac{1.0993}{1.0993+1.2068}=0.4769
\end{aligned}
$$

Maka didapatkan nilai tertinggi dimiliki oleh C6 dengan no register BI/098/2014.

\section{Metode Penelitian}

\subsection{Bahan Penelitian}

Dalam penelitian ini, bahan penelitian yang akan digunakan adalah data narapidana pada Lembaga Pemasyarakatan Klas II A Palu. 


\subsection{Bahan Penelitian}

Implementasi perangkat keras yang digunakan untuk membangun sistem pendukung keputusan rekomendasi pemberian remisi dengan spesifikasi Processor Core i3, RAM 2Gb, monitor dengan resolusi 1366x768 dan sistem operasi 32 bit.

Untuk implementasi perangkat lunak bahasa pemrograman yang digunakan yaitu Hypertext Preprocessor (PHP), media yang digunakan sebagai editor untuk membangun sistem yaitu Adobe Dreamweaver dan xammp sebagai penghubung ke database server Mysql dengan bahasa pemrograman.

\subsection{Lokasi Penelitian}

Penelitian ini dilakukan di Lembaga Pemasyarakatan Klas IIA Palu Sulawesi Tengah.

\section{Hasil dan Pembahasan}

\subsection{Implementasi Input}

1. Tampilan input bobot kriteria

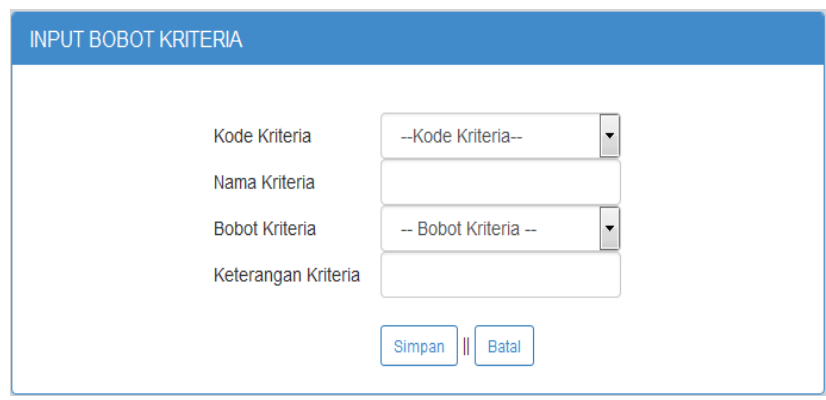

Gambar 5. Input bobot kriteria

Tampilan ini digunakan untuk memasukkan data kriteria dan nilai bobot pada setiap kriteria. Pada tampilan input bobot kriteria dilengkapi dengan tombol simpan dan batal dimana tombol simpan digunakan untuk menyimpan data inputan bobot kriteria kedalam database dan tombol batal digunakan untuk mambatalkan penyimpanan data bobot.

2. Tampilan input data narapidana

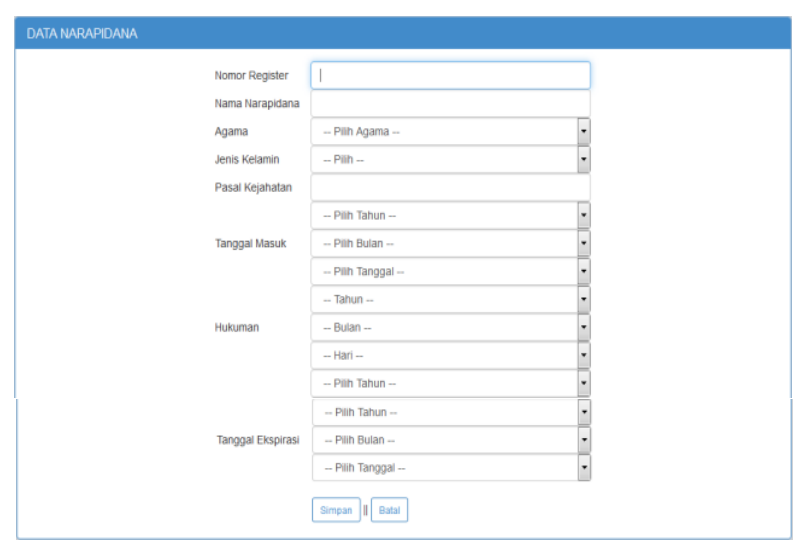

Gambar 6. Input data narapidana 
Tampilan ini digunakan untuk menyimpan data pribadi narapidana kedalam database dimana data yang tersimpan nantinya akan diolah untuk melihat data pribadi dari narapidana yang akan mendapatkan rekomendasi pemberian remisi.

3. Tampilan input penilaian narapidana

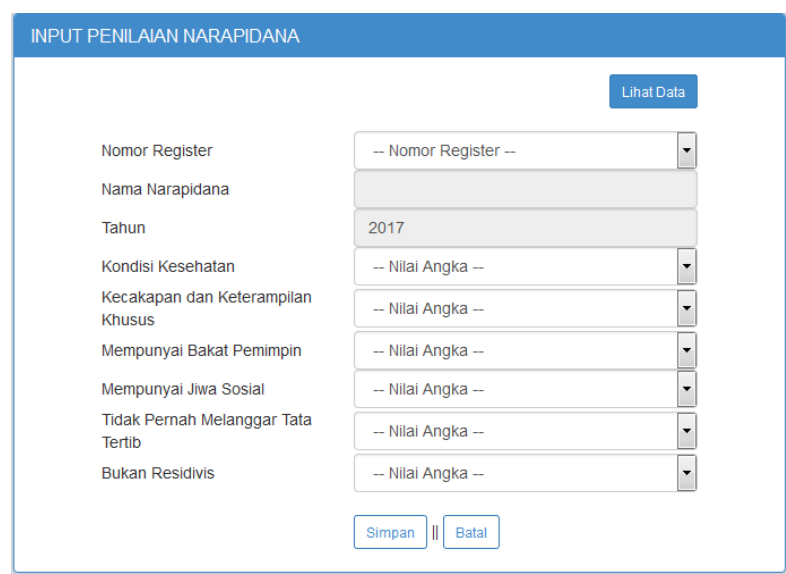

Gambar 7. Input penilaian narapidana

Tampilan ini digunakan untuk memasukan semua data penilaian narapidana berdasarkan kriteria yang telah ditentukan. Pada tampilan ini tersedia tombol lihat data dimana tombol tersebut dapat digunakan untuk melihat data-data penilaian yang telah dimasukkan dan tersimpan dalam database.

\subsection{Implementasi Output}

1. Tampilan data narapidana

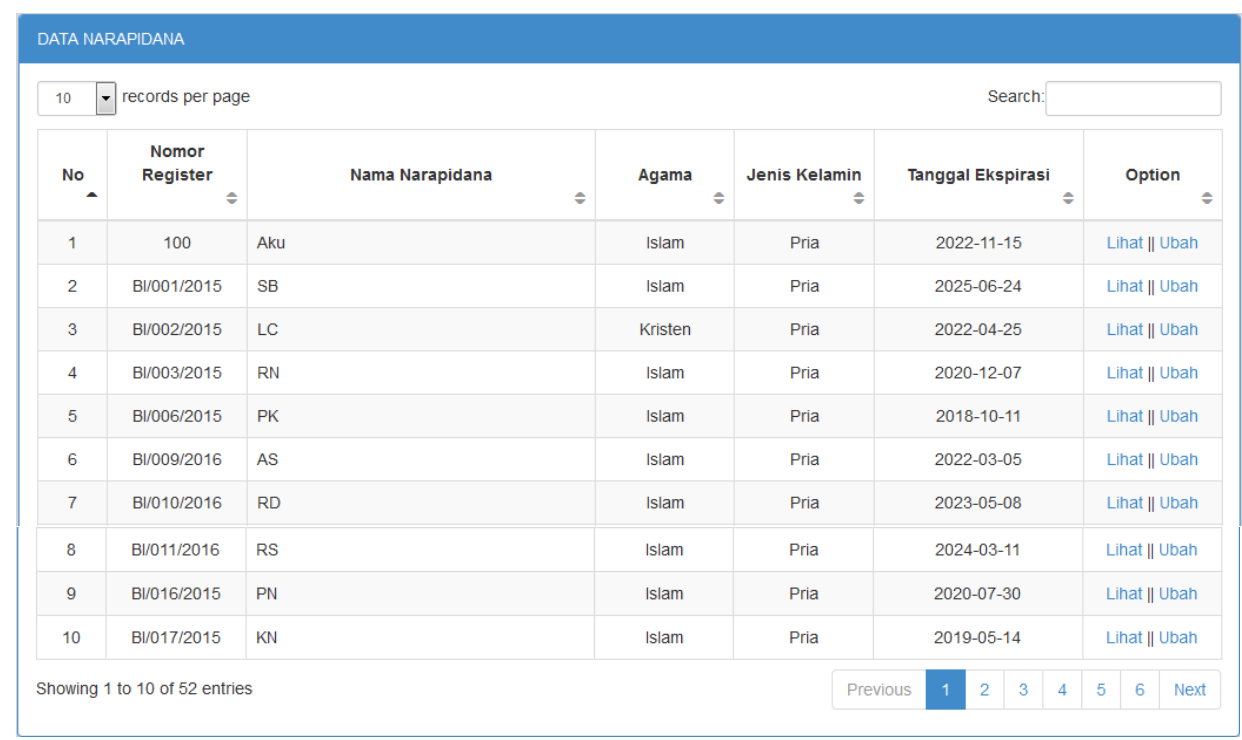

Gambar 8. Data narapidana

Tampilan ini digunakan untuk melihat semua data narapidana yang telah diinputkan kedalam database. Pada tampilan ini dilengkapi tombol lihat dan ubah. Tombol lihat digunakan untuk melihat 
semua data lengkap dari narapidana dan tombol ubah digunakan untuk mengubah data narapidana apabila terdapat data yang tidak sesuai.

2. Tampilan data penilaian

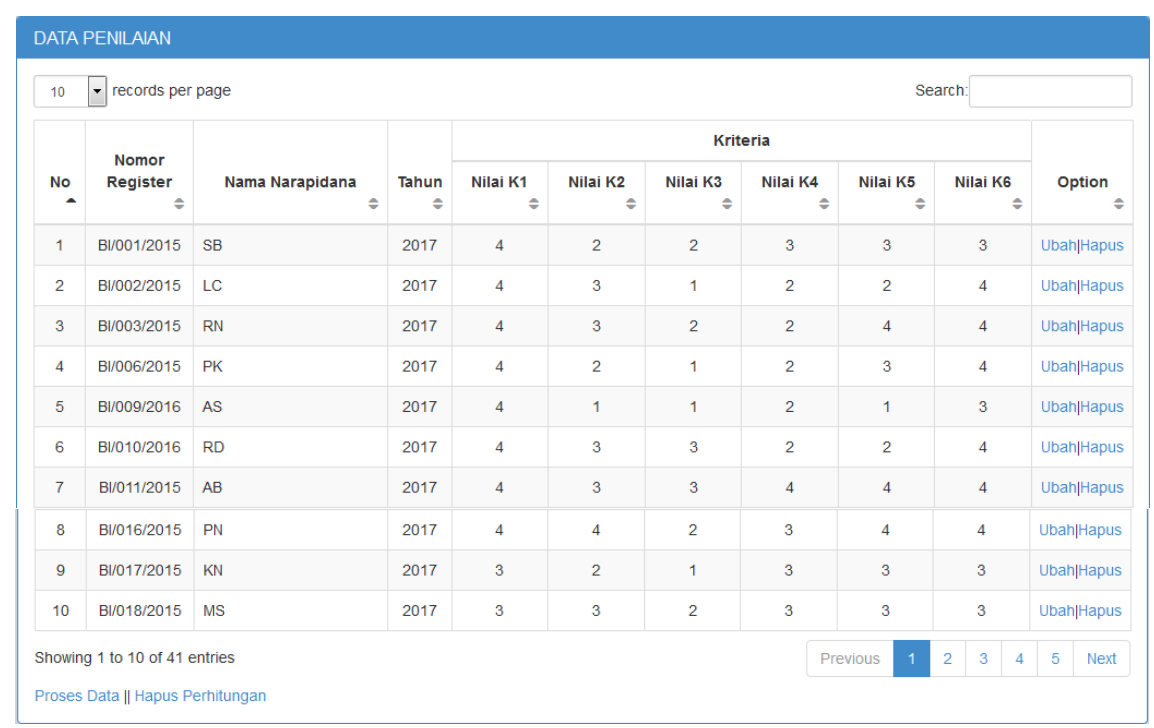

Gambar 9. Data penilaian

Tampilan ini digunakan untuk melihat hasil inputan penilaian narapidana yang telah tersimpan kedalam database. Pada tampilan ini dilengkapi dengan tombol ubah, hapus, proses data, hapus perhitungan. Pada setiap tombol mempunyai fungsi masing-masing, tombol ubah digunakan untuk mengubah data penilaian apabila terjadi salah penginputan nilai, tombol hapus digunakan untuk menghapus data narapidana yang telah dipilih, tombol proses data digunakan untuk melakukan proses penghitungan nilai menggunakan metode topsis dan tombol hapus perhitungan digunakan untuk menghapus proses perhitungan metode topsis yang telah dilakukan sebelumnya.

3. Tampilan hasil perhitungan

\begin{tabular}{|c|c|c|c|c|c|c|c|}
\hline \multicolumn{8}{|c|}{ HASIL PERHITUNGAN } \\
\hline \multicolumn{3}{|c|}{$10 \quad$ records per page } & \multicolumn{5}{|c|}{ Search: } \\
\hline No & Nomor Register & Nama Narapidana & $=$ & $\stackrel{\text { Tahun }}{=}$ & & Nilai Akhir & ir \\
\hline 1 & B/098/2014 & ED & & 2017 & & 0.613634 & \\
\hline 2 & Blo002/2015 & LC & & 2017 & & 0.350618 & \\
\hline 3 & B/154/2014 & MN & & 2017 & & 0.350618 & \\
\hline 4 & B/1001/2015 & SB & & 2017 & & 0.498237 & \\
\hline 5 & B/102/2014 & $\mathrm{RZ}$ & & 2017 & & 0.268542 & \\
\hline 6 & B/1048/2015 & $\mathrm{CR}$ & & 2017 & & 0.405597 & \\
\hline 7 & Blo50/2015 & TH & & 2017 & & 0.537447 & \\
\hline 8 & B//031/2015 & HM & & 2017 & & 0.432967 & \\
\hline 9 & B/197/2013 & DR & & 2017 & & 0.474212 & \\
\hline 10 & B/1006/2015 & PK & & 2017 & & 0.372998 & \\
\hline \multicolumn{3}{|c|}{ Showing 1 to 10 of 40 entries } & & Previous & 2 & \begin{tabular}{l|l}
3 & 4 \\
\end{tabular} & Next \\
\hline
\end{tabular}

Gambar 10. Hasil perhitungan 
Tampilan ini digunakan untuk melihat hasil dari proses perhitungan yang telah dilakukan menggunakan metode topsis. Pada tampilan ini terdapat tombol lihat rekomendasi dimana tombol tersebut digunakan untuk melihat hasil akhir rekomendasi pemberian remisi kepada narapidana.

\section{Kesimpulan}

Berdasarkan hasil pengujian dan analisis sistem pendukung keputusan rekomendasi pemberian remisi pada narapidana menggunakan metode Technique for Order Preferences by Similiarity to Ideal Solution(TOPSIS) dapat diambil kesimpulan:

1. Proses perhitungan dengan metode TOPSIS pada sistem pendukung keputusan ini dapat dilakukan dengan memasukkan nilai bobot kriteria dan penilaian yang diberikan kepada narapidana

2. Terdapat 6 langkah yang harus diperhatikan dalam penyelesaian menggunakan metode TOPSIS yaitu menentukan normalisasi matriks, matriks keputusan ternomalisasi terbobot, menetukan solusi ideal positif dan ideal negatif, menghitung separation measure ideal positif dan ideal negatif dan menghitung kedekatan dengan solusi ideal dan langkah terakhir yaitu mengurutkan pilihan.

3. Sistem pendukung keputusan ini dibangun menggunakan bahasa pemrograman Preprocessor HyperText (PHP) berbasis website dan sistem ini dapat membantu pegawai Lembaga Pemasyarakatan Klas IIA Palu dalam menentukan narapidana yang akan mendapatkan rekomendasi remisi dan sistem dapat mengurutkan data narapidana yang mendapatkan rekomendasi.

\section{Saran}

Pada penelitian ini masih terdapat beberapa kekurangan, sehingga diharapkan pada penelitian selanjutnya diperlukan perbaikan untuk pengembangan lebih lanjut, diantaranya:

1. Untuk setiap laporan tidak hanya dapat dicetak langsung tetapi juga dapat dikonversi kebentuk file dokumen Microsoft Excel atau Microsoft Word.

2. Perlu ditambahkan suatu metode atau algoritma yang dapat membandingkan nilai akhir apabila terjadi kesamaan nilai akhir agar dapat menentukan urutan peringkat terbaik.

\section{DAFTAR REFERENSI}

[1] Bonczek. 1980 Decision Support System And Intelligent Systems.Turban, 2005: 137.

[2] Creswell, J. 2008. Research Design Pendekatan Kualitatif, Kuantitatif, dan Mixed, Edisi Ketiga. Bandung: Pustaka Pelajar, 2008.h. 19.

[3] Kusumadewi, S., dkk. 2006. Fuzzy Multi-Attribute Decision Making (Fuzzy MADM). Yogyakarta: Penerbit Graha Ilmu.

[4] Nofriansyah, D. 2014. Konsep Data Mining Vs Sistem Pendukung Keputusan. Penerbit Deepublish, Yogyakarta, 2014.

[5] Nugroho, B. 2004. PHP \& MySQL dengan Editor Dreamweaver MX. Yogyakarta: Penerbit ANDI Yogyakarta.

[6] Sidik, B. 2001. Pemrograman Web dengan PHP. Bandung: Peneribit Informatika. 
[7] Sihotang, F. 2013. Sistem Pendukung Keputusan Penerima Beasiswa Dengan Metode Topsis (Studi Kasus: SMA Negeri 1 Parlilitan), STMIK Budi Dharma, Medan.

[8] Syahputra, A. 2014. Implementasi Sistem Pendukung Keputusan Pemberian Remisi Warga Rutan Kelas I Medan Menggunakan Metode Topsis, Universitas Sumatera Utara, Medan.

[9] Turban, E dan Aronson, J. 2001. Decision Support Sytem And Intelligent Systems.Narasimha Bolloju : Prentice Hall International.

[10] Wibowo, Y. 2013. Sistem Pendukung Keputusan Pemilihan Wilayah Pemasaran Baru Menggunakan Metode TOPSIS (Studi Kasus: PT. Puhan Indoneisa, Salatiga), Universitas Kristen Satya Wacana, Salatiga.

[11] Indonesia, Undang-Undang No. 12 Tahun 1995 Tentang Pemasyarakatan. LN No. 77 Tahun 1995, TLN No. 3614.P 